\title{
FUNGSI PREDIKATIF INTRANSITIF ADJEKTIVA BAHASA
} INDONESIA

\author{
Mirsa Umiyati \\ Universitas Warmadewa \\ mirsa.umiyati@warmadewa.ac.id
}

\begin{abstract}
Abstrak
Mengidentifikasi fungsi sintaksis kelas kata dalam konstruksi Bahasa Indonesia (selanjutnya disebut BI) selalu menantang untuk dituntaskan mengingat tipisnya batasan antar fungsi sintaksis dimaksud. Terlebih lagi menentukan fungsi sintaksis adjektiva dalam konstruksi kalimat BI, tantangan yang akan dihadapi tidak hanya menentukan batasan fungsi yang tepat namun kecermatan mengidentifikasi dan memilah mana yang adjektiva dan mana yang verba statif. Berangkat dari latar belakang tersebut, makalah ini menyajikan hasil analisis fungsi sintaksis adjektiva pada sejumlah tipe-tipe klausa pada BI. Hasil analisis menunjukkan bahwa adjektiva sangat dominan berfungsi sebagai subjek (SUBJ) klausal, baik sebagai inti NP Subjek maupun sebagai pewatas pentaraf pada NP Subjek dan NP Objek Klausal. Hasil analisis juga menunjukkan bahwa dari sejumlah tipe-tipe klausal BI, klausa relatif dan klausa komplemen serta klausa kompleks adalah tiga jenis klausa BI yang didominasi kemunculan adjektiva dalam fungsi sintaksis dominannya. Hasil analisis menyimpulkan bahwa fungsi sintaksis yang berterima pada suatu kelas kata dapat menjadi parameter penentu jenis kategori katanya.
\end{abstract}

Kata kunci: pewatas pentaraf, inti, klausa relatif, komplemen

\begin{abstract}
Identifying classes syntactic function of words in Indonesian construction (hereinafter referred to as BI) is always challenging to be completed given the thin boundaries between syntactic function in question. Moreover, determining the syntactic function BI adjective in sentence construction, the challenges to be faced not only determine the limits of proper function, but the accuracy identify and sort out which ones adjectives and verbs which ones stand. Departing from this background, this paper presents the results of the analysis of syntactic function adjectives on the number and type clause in BI. The analysis showed that the dominant adjective serves as a subject (Subj) clause, either as a core subject NP as well as modifiers pentaraf the subject NP and NP Object clauses. The analysis also showed that the number and type of BI clauses, relative clauses and complement clauses and complex clauses are three types of clauses BI dominated the emergence of dominant adjective in syntactic function. The results of the analysis concluded that the syntactic function that is acceptable in a class of words can be a parameter determining the type of category he said.
\end{abstract}

Keywords: modifiers, core, relative clauses, complement

\section{PENDAHULUAN}

Sebagai lambang pemersatu, sebagai bahasa nasional, Bahasa Indonesia (selanjutnya Disebut BI) memiliki kedudukan yang sangat penting dalam berbagai aktivitas pemerintahan dan aktivitas kenegaraan lainnya. Mengingat signifikasi kedudukan BI dimaksud, ambiguitas yang masih terdapat dalam struktur BI menjadi sangat menarik untuk dituntaskan. Ambiguitas Pertama yang selalu menjadi sorotan adalah kerancuan 
dalam pembagian kelas kata. Berbicara tentang pembagian kelas kata, hal ironis yang terjadi adalah, meskipun pembagian kelas kata merupakan penemuan linguistik paling tua dari zaman orang-orang Dianisia (100 SM), kelas kata justru menjadi bagian yang terbelakang untuk dipahami (Robins, 1989: 39). Lebih lanjut, Baker (1998:1) menyatakan bahwa, seringkali ketika seorang siswa masuk kelas linguistik untuk pertama kalinya, beberapa hal yang diketahuinya tentang tata bahasa adalah kategori kata nomina, verba, adverbia dan adjektiva (penulisan adjektiva mengacu pada Tata Bahasa Baku Bahasa Indonesia oleh Soenjono Dardjowidjojo, 1998; Alwi, dkk.2003; 2008).

Dampak dari ambiguitas pembagian kelas kata, sangat berpengaruh pada proses identifikasi fungsi sintaksis yang dapat diperankan oleh sejumlah kategori kelas kata tersebut dalam BI. Sebagai contoh, ketika konsep fungsi predikatif itu sudah sangat jelas teridentifikasi dalam suatu struktur kalimat, namun karena ambiguitas pembagian kelas kata masih rancu, maka yang terjadi adalah kita ragu-ragu dalam menentukan apakah fungsi Predikatif dalam kalimat dimaksud diduduki oleh adjektiva, verba atau nomina?. Hal tersebutlah yang mendorong ketertarikan untuk mengupas Adjektiva BI dalam fungsi Predikatif. Makalah dibatasi pada kelas dan adjektiva dalam bahasan fungsi Predikatif dengan pertimbangan bahwa kelas kata inilah yang sering dianggap sebagai trouble maker dalam ambiguitas yang terjadi dalam kategori kelas kata dalam BI. Hasil analisis berikut akan menunjukkan bukti perihal dimaksud.

\section{KONSEP DAN KERANGKA TEORI KONSEP}

\section{Struktur Konstituen (Str-k)}

Struktur konstituen (constituent structure atau $c$-str) adalah struktur yang berfungsi untuk mengatur hubungan ekspresi tata urut kata yang lebih nyata (Arka, 2003b:73; Alsina, 1996:16; Dalrymple, 2001:7). Struktur konstituen ini dibangun berdasarkan kaidah struktur frasa yang mengatur berbagai kemungkinan tata urut kata secara linier dan hierarki dalam setiap klausa atau kalimat. Kaidah struktur frasa secara konseptual mengikuti kaidah yang universal dalam teori $\mathrm{X}$-bar, misalnya struktur dikonsepsikan endosentris; artinya selalu ada porosnya (head) (Alsina, 1996:17; Arka, 2003b:73).

\section{Struktur Fungsi Gramatikal ( Str-f)}

Struktur fungsi (grammatical functional structure atau $f$-str) adalah struktur yang mengatur relasi gramatikal (dan semantis) yang dianggap lebih konsisten dan berisi properti yang bersifat (kurang-lebih) ajeg secara lintas bahasa 
(Arka, 2003b:73; Dalrymple, 2001:7) Relasi gramatikal yang dimaksudkan di sini adalah relasi fungsi sintaksis, yaitu relasi subjek, objek, oblik. Fungsi (gramatikal) dalam TLF dikaitkan dengan konsepsi bahwa relasi gramatikal (seperti SUBJ, OBJ, dsb.) dapat dimodelkan dengan struktur matriks dengan relasi gramatikal dan informasi lainnya membentuk pasangan atribut dan nilai dalam struktur formal, yang disebut struktur fungsional (Arka, 2003a: 145, 2003b:61; Alsina, 1996:18; Bresnan, 2001:47).

\section{Struktur Argumen (Str-a)}

Struktur Argumen (argument structure atau $a$-str) merupakan struktur tengahan atau struktur antara yang di dalamnya terkandung informasi, yaitu (a) informasi mengenai valensi verba (seperti verba berargumen satu, verba berargumen dua, verba berargumen tiga); (b) informasi mengenai keintian argumen (argumen inti dan argumen noninti); dan (c) informasi mengenai prominansi satu argumen yang memiliki: (i) inti mengalahkan noninti, dan (ii) dalam rangkaian inti dan noninti ini prominansi menggambarkan prominansi semantik (Arka, 1998, 2003a, 2003b; Manning, 1996; Alsina, 1996).

\section{Struktur Semantik (Str-sem)}

Struktur semantis (semantic structure atau sem-str) menggambarkan kandungan semantis bentuk linguistik, khususnya verba sebagai predikator. Komponen-komponen makna yang bersesuaian secara sintaktis (keadaan ini memungkinkan untuk mendapatkan aturanaturan pemetaan) diungkapkan dalam pengertian leksikal (Arka, 1998:197; Foley dan Van Valin, 1984). Dalam pendekatan ini, str-sem terdiri atas unit-unit semantis yang terstruktur dari kompleksitas yang berbeda. Str-sem memiliki peringkat yang membatasi prominansi relatif di antara variabel atau argumen (Arka, 1998:200201).

\section{KERANGKA TEORI}

Teori Tata Bahasa Leksikal-Fungsional (Lexical-Functional Grammar)

TLF dirancang menjelang akhir tahun 1970, namun uraian secara detail baru dilakukan pada tahun 1982 oleh Ronald M. Kaplan dan Joan Bresnan. Kedua ahli tersebutlah sebagai pelopor yang memunculkan TLF. TLF dibangun dengan memadukan beberapa ide yang berkaitan dengan pertimbangan komputasional dan penyelidikan linguistik yang diadakan pada tahun 1970 (Dalrymple, dkk.(Ed.), 1995:1; Sells, 1985:135; Kaplan dan Bresnan, 1995:30; Bresnan, 2001:4; Falk, 2001:3). Tata Bahasa Leksikal - Fungsional tergolong ke dalam tata bahasa generatif yang 
nontransformasional yang berbasiskan leksikon (Bresnan, 2001:4; Dalrymple, 2001:1; Falk, 2001:2; Arka, 2003b:64). Sebagai bagian dari teori generatif, TLF mengacu pada konsep dasar generatif, yaitu tata bahasa terdiri atas seperangkat modul, prinsip-prinsip tertentu, dan kendalakendala tertentu yang membentuk suatu mekanisme yang mampu menghasilkan ekspresi bahasa yang tidak terbatas jumlahnya (Arka, 1998; 2003b:60 - 61).

Berbeda dengan tata bahasa transformasional, $\quad$ TLF tidak mengasumsikan adanya transformasi, yakni pengubahan 'struktur batin' menjadi 'struktur lahir' dengan mekanisme perpindahan (movement). Berbagai alternasi ekspresi lahir, seperti aktif-pasif yang dianalisis sebagai hasil transformasi oleh GB (Government Binding), dianalisis sebagai proses leksikal oleh TLF. Proses leksikal yang dimaksud mencakup perbedaan proses pemetaan (lihat Arka, 2003b:61). Lebih lanjut dijelaskan pula bahwa kata 'leksikal' dalam TLF mengandung implikasi makna yang mengisyaratkan peran yang sangat penting bagi informasi dan proses leksikal. Artinya, selain mengandung entri leksikal yang menunjukkan berbagai informasi yang dibawa oleh unit-unit leksikal (kata dan afiks), leksikon juga merupakan tempat terjadinya berbagai proses pembentukan kata atau unit leksikal baru yang berdasarkan berbagai prinsip dan kendalakendala yang bersistem.

TLF menjadikan entri leksikal sebagai tumpuan, dengan asumsi dasarnya bahwa suatu unsur dapat digabungkan dengan atau bisa menghadirkan unsur lain untuk membangun sebuah konstruksi, sangat tergantung pada unsur leksikal itu sendiri (Kaplan dan Bresnan, 1995:30-31; Sells, 1985:136; Wescoat dan Zaenen, 1991:108). Itu berarti bahwa unsur leksikal sangat berperan sebagai faktor penentu untuk membangun sebuah konstruksi kebahasaan, termasuk konstruksi kalimat.

Selain kata 'leksikal' seperti dijelaskan di atas, juga perlu dijelaskan pengertian kata 'fungsional' dalam teori ini agar bisa dibedakan dengan istilah fungsional pada teori lain. Kata 'fungsional' dalam TLF dipakai dalam pengertian 'fungsi matematis'. Fungsi dalam TLF dikaitkan dengan konsepsi bahwa relasi gramatikal, seperti SUBJ, OBJ, dan sebagainya, dapat dimodelkan dengan struktur matriks dengan relasi gramatikal dan informasi lainnya membentuk pasangan atribut dan nilai (value) dalam struktur formal, yang disebut struktur-fungsional (str-f). Karenanya, SUBJ, OBJ, dan OBL adalah fungsi gramatikal dalam TLF (lihat Arka, 2003b:61). 
Dalam hubungannya dengan peran, TLF mengekspresikannya dalam bentuk skema fungsional (functional schemata) yang dihubungkan dengan tanda anak panah $(\rightarrow)$ yang ditempatkan pada posisi kanan (Wescoat dan Zaenen, 1991:107). Contohnya seperti pada (1), (2), dan (3) berikut.

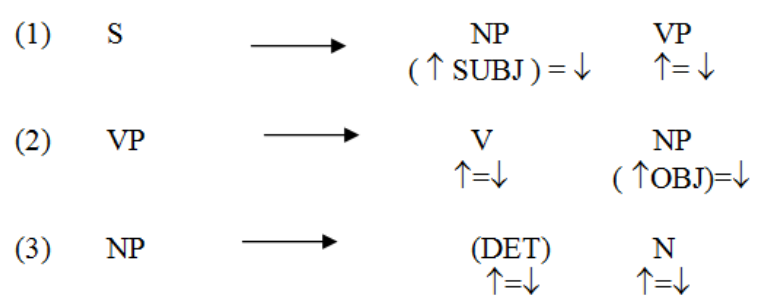

Ekspresi $(\uparrow$ SUBJ $)=\downarrow$, dan $(\uparrow$ OBJ $)=\downarrow \quad$ semuanya merupakan skema fungsional dan ditulis di bawah simbol yang diasosiasikan dengan peran. Simbol tanda panah $(\uparrow)$ dan $(\downarrow)$ yang biasa digunakan dalam skema fungsional, disebut metavariabel (metavariables). Metavariabel dengan tanda anak panah ke bawah $(\downarrow)$, disebut EGO atau SELF, sedangkan tanda anak panah ke atas ( $\uparrow)$, disebut metavariabel MOTHER. Metavariabel naik ( $\uparrow)$ dan turun ( $\downarrow$ ) berfungsi untuk menengahi (menghubungkan) struktur konstituen (str-k) dan struktur fungsional (str-f.) (Wescoan dan Zaenen, 1991:110). Dengan adanya metavariabel tersebut pada str-k, maka kekeliruan penempatan fungsi gramatikal pada str-f bisa terhindari

Skema fungsional selalu disertakan dengan satuan-satuan leksikal. Entri leksikal biasanya ditulis seperti pada (4), (5), (6), dan (7) berdasarkan contoh kalimat bahasa Inggris John sees Mary (Wescoat dan Zaenen, 1991:104) berikut.
(4) John sees Mary
(5) John
$\mathrm{N}(\uparrow \mathrm{PRED})={ }^{\prime} \mathrm{JOHN}{ }^{\prime}$
$(\uparrow N U M B E R)=$ SING
$(\uparrow$ PERSON $)=3$
(6) sees
$\mathrm{V}(\uparrow \mathrm{PRED})=$ 'SEE $<(\uparrow \mathrm{SUBJ})(\uparrow \mathrm{OBJ})>$
$(\uparrow$ SUBJ NUMBER $)=\mathrm{SING}$
$(\uparrow S U B J$ PERSON $)=3$
( $\uparrow$ TENSE) $=$ PRESENT
(7) Mary

\section{$\mathrm{N}(\uparrow \mathrm{PRED})=$ 'MARY' \\ $(\uparrow N U M B E R)=$ SING}
$(\uparrow$ PERSON $)=3$

Pada contoh (5), (6), dan (7) di atas tampak bahwa tiap-tiap entri leksikal mengandung tiga hal, yaitu representasi bentuk satuan, kategori sintaksis yang termasuk dalam unit itu, dan daftar skema fungsional.

Pada mulanya (sekitar tahun 1982), dalam teori TLF, tata bahasa dikonsepsikan sebagai suatu sistem yang terdiri atas struktur paralel. Struktur paralel yang terpenting dalam TLF klasik untuk mendeskripsi kalimat pada setiap bahasa di dunia terdiri atas dua struktur paralel, yaitu struktur konstituen (str-k) dan struktur fungsional (str-f). Ide yang melatarbelakangi adanya pemisahan kedua struktur paralel tersebut adalah untuk menangkap sifat tipologis bahasa (Kaplan dan Bresnan, 1995:31; Wescoat dan Zaennen, 1991:108; Sells, 1985:135; Dalrymple, 1993:100, 2001:7; Arka, 
2003:72). Setiap jenis representasi lahir relasi sintaksis tersebut (str-k dan str-f) membawa jenis informasi yang berbeda: str -k mengandung informasi tentang dominasi (dominance), tata urut (precedence), dan relasi konstituen (constituent relations); sedangkan str-f mengandung informasi fungsional sintaksis mengenai nosi, seperti struktur argumen sintaktis dan adjung. Jadi, pada str-f berisi gabungan nama-nama fungsi gramatikal, bentuk-bentuk semantis, dan simbol-simbol khusus (Kaplan dan Bresnan, 1995:31).

Lebih jauh lagi Arka (2003b:73) mengungkapkan kenyataan yang menunjukkan bahwa adanya keragaman ekspresi lahir (misalnya tata urut dan kekompleksitasan morfologis) bahasa di dunia pada satu sisi, hasil penelitian kebahasaan juga menunjukkan bahwa bahasa-bahasa di dunia mempunyai banyak kesamaan pada sisi lain, sehingga generalisasi dan kesemestaan bahasa bisa dikonsepsikan. TLF menangkap keberagaman dan kesemestaan tersebut melalui str-k dan str-f. Str-k berfungsi mengatur ekspresi tata urut kata yang lebih nyata dan bisa sangat bervariasi dari satu bahasa ke bahasa lainnya, sedangkan str-f mengatur relasi gramatikal (dan semantis) yang lebih konsisiten dan berisi properti yang bersifat (kurang lebih) ajeg secara lintas bahasa
Meskipun representasi str-k dan str-f berbeda antara satu dengan lainnya, kedua representasi struktur tersebut tetap merupakan satu-kesatuan dalam penganalisisan data secara TLF. Perumusan str-f akan terasa lebih mudah, apabila dilakukan melalui penyusuna str-k terlebih dahulu, walaupun kedua hal itu tidak selalu dilakukan secara berurutan atau langkah demi langkah. Tidak selalu str-f dikerjakan setelah mengerjakan str-k.

Sebuah str-k ditentukan oleh tata bahasa yang mencirikan semua struktur lahir (surface structure) pada suatu bahasa, bukan struktur batin (deep structure). Tata bahasa itu diungkapkan dalam sebuah konteks formalisme bebas atau yang dimodifikasi secara formal seperti jaringan kerja transisi yang berulang-ulang (recursive). Kalimat bahasa Inggris John sees Mary pada contoh (4) di atas, dapat dibuatkan str-k seperti tampak pada diagram (8) berikut. 
(8)
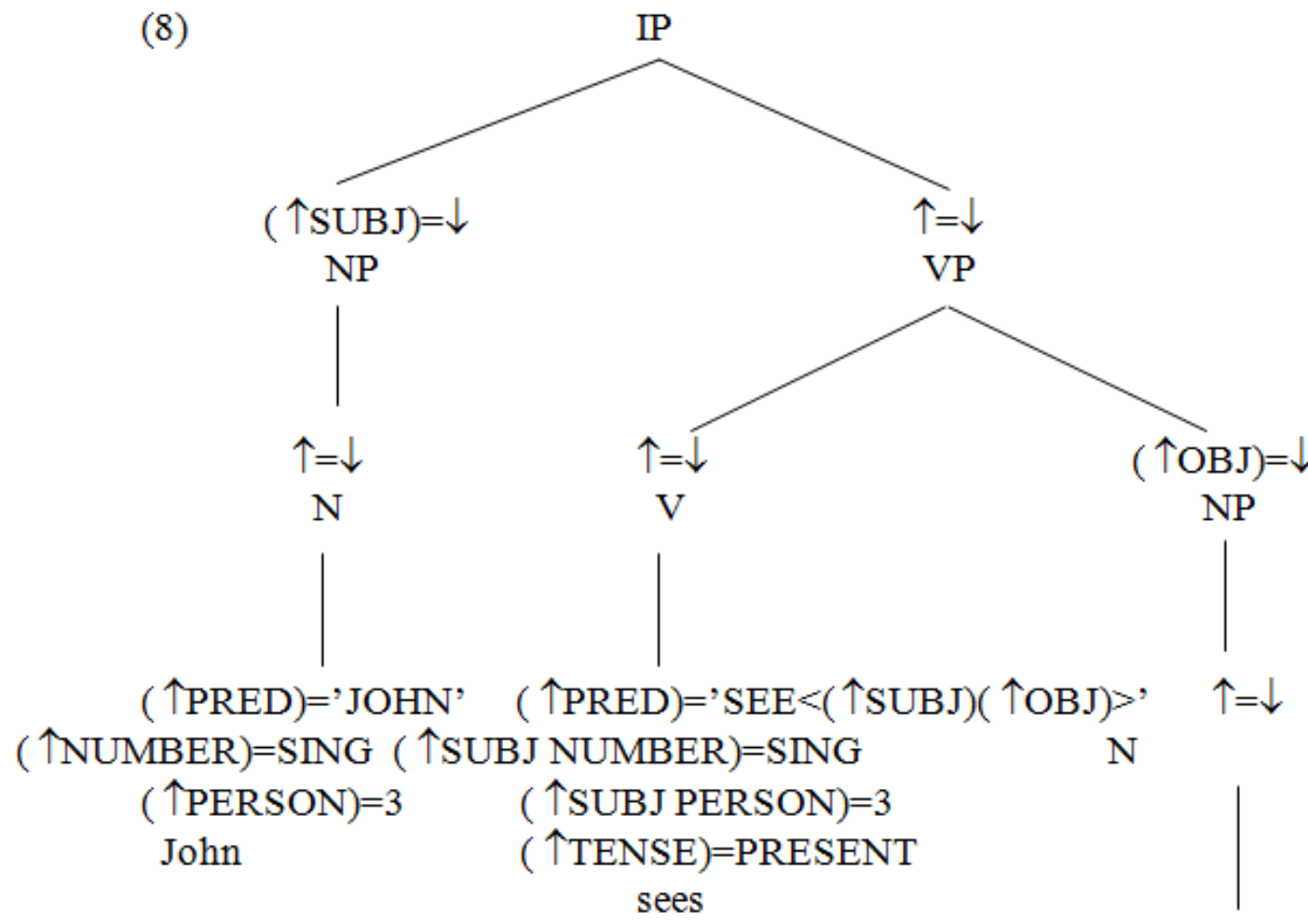

$\mathrm{N}$

$\uparrow=\downarrow$

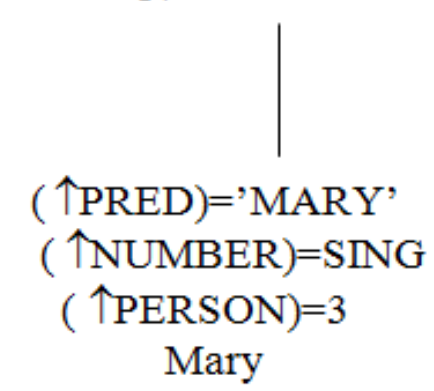

Struktur fungsional memiliki matriks struktur predikat. Secara lengkap, Dixon berupa atribut dan nilai (value) yang (2010: 110) menjabarkan struktur predikat keduanya ditulis secara horizontal pada dimaksud yang dijadikan kriteria penentu baris yang sama. Setiap atribut diasosiasikan dengan sebuah nilai (single value). Dengan demikian, setiap atribut hanya boleh memiliki sebuah nilai (Dalrymple, 1993:100; Kaplan dan Bresnan, 1995:32).

\section{PEMBAHASAN}

\section{Fungsi Predikat Intransitif}

Predikat merupakan konstituen inti dalam suatu klausa atau kalimat. Suatu kategori kata dapat dikatakan sebagai predikat apabila dapat memenuhi kriteria fungsi predikat sebagai berikut. Subject marker obligatory, Tense or aspect marker optional, Pre-head modifier (optional), Head (obligatory), plus suffix if transitive, Object pronoun (if transitive), Post head modifier and or adverb (optional). Beberapa kriteria struktur predikat yang dirumuskan Dixon di atas akan menjadi parameter penentu sekaligus argumen dari peneliti mengapa adjektiva dapat dikatakan berperan dalam beberapa fungsi predikat, yang dijabarkan sebagai berikut.

Fungsi predikat intrasitif adalah 
fungsi pengisi slot predikatif dalam klausa intransitif. Klausa intransitif adalah klausa yang terdiri dari satu predikat sebagai satusatunya konstituen inti dan satu argumen inti yang berupa argumen SUBJ yang berada mendahului kemunculan predikat dalam klausa. Dalam BI, kategori yang dapat mengisi slot predikat intransitif tidak hanya verba intransitif itu sendiri, namun juga kategori lain yang dapat memenuhi parameter fungsi predikat dalam klausa seperti tersebut di atas, yaitu kehadiran argumen SUBJ dan fungsinya sebagai konstituen predikat klausa intransitif. Kategori lain dimaksud adalah kategori adjektiva dan nomina (makalah ini tidak terfokus pada kelas kata nomina dalam fungsi dimaksud)

Bahasa Indonesia adalah bahasa yang dalam strukturnya memperbolehkan kategori kata lain mengisi slot predikat dalam klausa intransitif. Adjektiva adalah satu dari tiga kategori kata lainnya yang memungkinkan mengisi fungsi dimaksud. Namun yang harus dianalisis lebih tajam adalah membedakan keduanya disaat memerankan fungsi yang sama. Dixon (2010:77) menjabarkan bahwa kemungkinan perbedaan tersebut terletak pada (1) kemungkinan posisi diantara slot predikat yang berbeda; (2) kemungkinan transitivitas yang berbeda;

kemungkinan berfungsi sebagai modifier
NP yang berbeda; (4) kemungkinan berada dalam konstruksi komparatif yang berbeda dan (5) kemungkinan memerankan fungsi adverbial dalam fungsi menerangkan verba yang berbeda.

Adjektiva yang memerankan fungsi sebagai pengisi slot predikat intransitif akan memiliki lingkungan yang berbeda sebelum dan sesudah kemunculannya sebagai pengisi slot yang menentukan tersebut. Lingkungan berbeda yang dimaksud diantaranya terkait dengan proses morfologis dan kemunculan modifier secara sintaktis. Terkait proses morfologis, adjektiva BI yang berfungsi sebagai predikat intransitif lebih bertahan dibandingkan dengan verba dengan fungsi yang sama.

Sebagai inti dari predikat intransitif, adjektiva hanya bisa menerima pronomina yang berfungsi sebagai proklitik sebagai sufiks. Pronomina yang berterima dilekati adjektiva dalam fungsi predikatif intransitif adalah pronomina (nya-) dan $(k u-)$. Pelekatan pronomina terhadap adjektiva berfungsi sebagai proklitik dan bukan afiks yang membentuk turunan adjektiva. Adjektiva lebih bertahan dalam bentuk dasarnya dan atau memilih menjadikan bentuk dasar tersebut dalam struktur frasa akibat pelekatan pewatas tertentu daripada menerima sejumlah afiks pembentuk adjektiva turunan dalam fungsi ini, seperti 
yang diperlihatkan dalam data berikut.

1. Cinta itu bodoh. (DSCB : 2005)

Terlihat dari data di atas, adjektiva lebih memilih bentuk dasarnya daripada bentuk turunan pelekatan afiks tertentu dalam memerankan fungsi predikat intransitif. Data lebih banyak dalam fungsi tersebut. Satu-satunya proses morfologis yang berterima pada adjektiva dalam memerankan fungsi ini adalah proses reduplikasi. Dalam bentuk turunan akibat proses gramatikal ini, ditemukan sejumlah data adjektiva dapat memerankan fungsi pengisi slot predikatif seperti yang terlihat dalam data berikut.

2. Cewek Jakarta memang cantik-cantik. (DBAD : 2010)

3. Katanya dengan suara amat lemah. (DTW, 2007: 87, 18-19)

Untuk mempertahankan bentuk dasarnya, suatu adjektiva memilih membentuk struktur frasa dalam memerankan fungsi predikatif intransitif seperti yang terlihat dalam data berikut.

4. Bandi terlalu polos. (SABM : 2009)

5. Cintanya sangat indah. (DBAD : 2010)

6. Mulanya hidup kami memang sangat sulit (DTW:2007)

7. Di sana pergaulannya sangat bebas. (KNI : 2009)

8. Sikapnya terhadap ibu Trianto sangat

\section{hormat (KNI:2009)}

9. Perjalanan ke puncak masih sangat jauh (SBDPS:1999)

Terlihat dalam data di atas, frasa adjektiva yang potensial memerankan fungsi predikat intransitif adalah frasa adjektiva yang dibentuk dari gabungan adjektiva pentaraf dan adjektiva; gabungan dobel adjektiva pentaraf dan adjektiva dan gabungan modalitas dan pewatas adverbial dalam membentuk frasa adjektiva seperti yang terlihat dalam data berikut.

10. Saya benar-benar sedang teramat sangat sibuk (PDUP)

Terlihat dalam data di atas, adjektiva yang berfungsi sebagai pengisi slot predikat intransitif muncul dalam klausa intransitif yang hanya menampilkan argumen SUBJ sebagai satu-satunya argumen dalam klausa. Model konstruksi tersebut cenderung dimainkan oleh adjektiva jenis properti manusia. Adjektiva jenis nilai yang bisa dilekatkan untuk properti manusia dan properti non-manusia cenderung tampil dalam klausa yang tidak hanya menampilkan unsur argumen inti SUBJ yang mendahuluinya, namun juga diikuti oleh argumen noninti yang berfungsi sebagai adjung seperti yang terlihat dalam data berikut.

11. Musim gugur sangat lembab di Kobe. 
(JNH:2005)

12. Aku merasa sangat sehat sampai rasanya sanggup lari maraton (SABM:2009)

13. Aku sudah sangat sabar sampai suamiku kawin lagi (DTW:2007)

14. Aku sangat khawatir akan hasil ujian yang baru lalu.(S)

15. Prambudi sangat marah ketika akhirnya Bing dibebaskan. [CMDB:2010]

Terlihat dalam data di atas, argumen noninti fungsi adjung yang berada sesudah frasa adejktiva yang berfungsi predikatif intransitif membutuhkan konjungsi tertentu apabila unsur non-inti yang mengikutinya adalah frasa yang memperjelas makna frasa adjektiva dalam fungsi tersebut, seperti yang terlihat data (11)-(15), konjungsi sampai pada data (11) dan (12) muncul sebagai pemarkah kehadiran frasa atau klausa komplemen yang berfungsi sebagai adjung, demikian pula konjungsi akan pada data (13) dan ketika pada data (14) yang berperan sama, yaitu sebagai pemarkah kemunculan adjung dalam klausa tersebut. Selanjutnya terlihat dalam data di atas, adjung yang kehadirannya muncul melalui kehadiran frasa preposisi tidak memerlukan kehadiran konjungsi yang menandai kehadiran argumen non-inti dalam klausa intransitif seperti yang terlihat dalam data
(11) frasa preposisi di Kobe dapat menduduki fungsi tersebut tanpa pemarkah kehadiran yang wajib hadir dalam klausa intransitif.

Sangat mendasar perbedaan adjektiva dan verba sebagai pengisi slot predikat intransitif apabila diperbandingkan dari sisi kemungkinan transitivitasnya. Hampir semua verba dapat digunakan secara intransitif. Beberapa verba yang berperilaku secara intransitif memperlakukan subyek intransitif (S) terhubung dengan subyek transitif (A), sedangkan sebagian verba yang lain cenderung memperlakukan subyek intransitif (S) terhubung dengan obyek transitif $(\mathrm{P} /$ O) secara transitif. Verba BI yang secara tipologis bertipe ergatif secara sintaktis cenderung memperlakukan subyek intransitif $(\mathrm{S})$ terhubung dengan obyek transitif $(\mathrm{P} /$ O) secara transitif. Data berikut dapat menunjukkan perilaku dimaksud.

Adjektiva adalah kategori kata yang dapat memerankan fungsi sebagai pengisi slot predikat intransitif, namun adjektiva tidak dapat berperan dalam fungsi yang sama dalam klausa transitif. Oleh karena itu, tidak seperti verba, adjektiva tidak dapat dilekati afiks pembentuk verba transitif. Dasar itulah yang menyebabkan kategori adjektiva hanya bisa muncul mengisi slot predikat intransitif dan bukan predikat transitif. Dengan demikian, dalam berbagai kemungkinan transitivitas, adjektiva hanya 
memiliki subyek intransitif $(\mathrm{S})$; tidak memiliki subyek transitif (A) dan tidak memiliki obyek transitif $(\mathrm{P} / \mathrm{O})$. Menjadi pertanyaan, bagaimana perilaku adjektiva BI dalam memperlakukan subyek intransitif (S) nya?.

Berbeda dengan adjektiva, verba mempunyai sejumlah kata yang hanya dapat dipergunakan sebagai verba intransitif saja; ada sejumlah kata yang memungkinkan dipergunakan sebagai verba intransitif dan transitif. Meskipun demikian, uniknya, sejumlah kata BI memungkinkan hanya dipergunakan sebagai adjektiva saja dan juga ada sejumlah kata yang memungkinkan dipergunakan sebagai adjektiva dan verba berkategori verba intransitif dan bukan verba transitif. Sangat sulit menentukan sikap apakah ejumlah kata dimaksud adlah kata-kata yang dikelompokkan dalam kata yang berkategori ganda (brkategori verba dan adjektiva); ataukah sejumlah kata tersebut adalah kata berkategori adjektiva dengan sub-bagian berkategori adjektiva menyerupai verba ataukah sejumlah kata tersebut berkategori verba dengan subbagian berkategori verba yang menyerupai adjektiva. Dalam berbagai kasus, sejumlah kata tersebutlah yang diklaim sebagai verba statif yang kemudian diderivasi ke dalam kategori adjektiva karena fungsi yang diperankannya.

Adjektiva yang memerankan fungsi sebagai pengisi slot predikat intransitif dapat memiliki model struktur yang berbeda dengan model struktur klausa intransitif yang berpredikat verba intransitif dasar dan turunan. Beberapa model struktur yang terbentuk secara bervariasi tersebut disebabkan oleh dua hal, (1) keragaman bentuk struktur farsa adejktiva yang dapat berperan sebagai predikat intransitif dan (2) Jenis nomina dan ragam model frasa nomina yang berfungsi sebagai argumen SUBJ yang muncul mendahului konstituen predikat intransitif yang diperankannya. Berikut akan dijabarkan keragaman model klausa intransitif berpredikat adjektiva dimaksud sebagai berikut.

\section{A. $S=$ Pronomina dan PRED $=$ FAdj}

\section{$\{$ Negasi + Adjektiva $\}$}

Model klausa intransitif yang berpredikat adjektiva yang pertama yang ditemukan dalam data adalah pronomina yang berfungsi sebagai frasa nomina $(\mathrm{FN})$ dan frasa adjektiva (FAdj) yang berfungsi sebagai predikat intransitif seperti yang ditunjukkan pada data berikut.

Kami tidak bahagia (BIP, 2003: 125, 28)

Terlihat dalam data (1) di atas, frasa adjektiva tidak bahagia adalah frasa pengisi slot predikat dalam klausa intransitif. Frasa tersebut dikatakan berfungsi predikatif karena frasa tersebut memenuhi dua syarat minimum penentuan struktur 
predikat yang harus melekat padanya. Terlihat dalam data di atas kemunculan pronomina kami sebagai penanda kata ganti orang kedua jamak yang berfungsi sebagai subyek (SUBJ) memenuhi syarat pertama suatu kategori dikatakan sebaagai pengisi slot predikatif intransitif. Tidak ada keraguan bahwa suatu pronominal dapat berfungsi sebagai SUBJ dalam BI, sehingga ketidakhadiran pemarkah SUBJ mendahului atau sesudahnya tidak merupakan penyebab gugurnya kriteria pertama. Alasan selanjutnya mengapa frasa adjektiva tidak bahagia di atas dikatakan sebagai predikat intransitif adalah terpenuhinya kehadiran unsur inti yang menjadi syarat wajib suatu klausa kata/klausa dikatakan memerankan fungsi predikat.

Terlihat dalam data di atas, klausa kami tidak bahagia menempatkan kami sebagai argumen non-inti dari frasa adjektiva tidak bahagia yang berfungsi sebagai inti klausa dimana bahagia merupakan inti dari frasa tidak bahagia. Kalimat di atas memberikan kita satu model bentukan klausa intransitif yang menempatkan frasa adjektiva sebagai predikat. Model dimaksud ditampilkan dalam tabel berikut.

\section{KLAUSA INTRANSITIF $1=$ (S) Kata Ganti Orang Kedua (+) (P) Frasa Adjektiva \{negasi tidak + adjektiva nilai\}}

Perhatikan contoh berikut untuk melihat variasi model frasa adjektiva yang terlihat dari data di atas, klausa intransitif yang menempatkan frasa adjektiva sebagai predikatnya terbentuk dari frasa adjektiva bentukan negasi dengan FN yang diperankan oleh pronominal tanpa memarkah pemisah fungsi keduanya.

\section{B. $\mathbf{S}=\mathbf{N}(+)$ F Adj \{Pewatas Adverbia + Adjektiva\}}
17. Ardila semakin bingung. (BIP, $2003: 298,11)$

18. Ibu cantik sekali. (BIP,2003:18,8-12)
Data di atas menunjukkan dua parameter minimum yang harus dipenuhi kategori kata yang dapat memerankan fungsi predikat intransitif, yaitu pertama, kemunculan SUBJ berupa Nomina Tunggal Ardila pada data (2) dan (4) juga nomina Ibu pada data (3). Syarat minimum kedua adalah munculnya inti (head) klausa, yaitu frasa adjektiva semakin bingung pada data (2), cantik sekali pada data (3) dan begitu marah pada (4). Kedua frasa di atas dapat dikategorikan sebagai frasa yang berstruktur predikat karena mempunyai batas yang jelas antara kedudukan predikat dan SUBJ yang diwatasi oleh kehadiran adverbial yang membatasi fungsi SUBJ dan predikat. 
Berkategori predikat intransitif karena SUBJ adalah satu-satunya argumen yang diperlukan dan diminta oleh predikat klausa di atas. Ketiga klauasa di atas men- gantar kita pada model klausa intransitif berpredikat frasa adjektiva yang kedua sebagai berikut:

\section{KLAUSA INTRANSITIF $2=$ (S) Nomina Tunggal $(+)$ (P) Frasa Adjek- tiva \{pewatas adverbia + adjektiva nilai properti manusia\}}

Data berikut dipisahkan dari data sebelumnya karena meskipun sekilas model bentukannya hampir sama, namun data menunjukkan kemunculan argumen noninti sesudah kemunculan predikat intransitif.

\section{C. $S=N(+)$ FAdj \{Adverbia + Adjek- tiva + keterangan/ADJ $\}$}

Meskipun kemunculannya tidak men- gubah makna dan memberikan keterangan tambahan dalam kemunculannya yang bersifat opsional, model ini memberikan model tersendiri seperti yang terlihat dalam data berikut.

19. Ardila begitu marah pada Arnold. (BIP, $2003: 310,25-27)$

\section{KLAUSA INTRANSITIF $3=$ (S) Nomina Tunggal $(+)$ (P) Frasa Adjek- tiva \{pewatas adverbia + adjektiva nilai properti manusia $\}+$ Keterangan/ADJ}

Perhatikan data berikut untuk perbandingan model klausa intransitif berpredikat verba intransitif dalam data berikut.

20. Suster gemuk itu mengalah. (DTW, $2007: 190,20)$

Data klausa intransitif berpredikat verba intransitif di atas dipisahkan pemarkah predikat yang jelas, yaitu kata ganti demonstratif itu yang menjadi elemen pembentuk frasa nomina suster gemuk itu. Disamping berfungsi sebagai elemen pem- bentuk FN, Kemunculan kata demonstratif itu sekaligus menjadi pembatas yang jelas antara SUBJ dan fungsi predikat yang diperankan oleh verba mengalah. Kondisi itulah yang menyebabkan kata ganti demonstratif dimaksud didefinisikan sebagai pemarkah SUBJ dan fungsi predikat.

Dengan demikian, syarat kemunculan struktur predikat klausa intransitif sudah terlihat dengan sangat jelas. Syarat pertama adalah adanya pembatas antara fungsi SUBJ dan PRED dalam klausa. Syarat yang lain yang wajib muncul adalah ke- 
haadiran inti klausa. Terlihat dalam data di atas, suter gemuk itu adalah satu-satunya argumen inti yang diminta oleh satusatunya konstituen predikat yang diperankan oleh verba intransitif mengalah.

D. $\mathbf{S}=$ FN diwatasi Demonstratif itu $(+)$ Adj

Menjadi pertanyaan, bagaimana dengan adjektiva?, bisakah adjektiva yang berfungsi sebagai predikat intrasitif mempunyai pola/model yang menempatkan kata ganti demonstratif itu sebagai pemarkah SUBJ sekaligus penanda kehadiran struktur predikat. Data berikut akan menjawab pertanyaan dimaksud sebagai berikut.
21. Cinta itu buta. (DTW, 2007: 105, 11)

22. Jalan itu sempit dan sepi. (BIP, 2003 : $73,8)$

23. Kamu muda dan cantik. (BIP, $2003: 219,8-9)$

Terlihat dalam data di atas, kata ganti demonstratif itu disamping merupakan pembatas fungsi SUBJ dan predikat yang diperankan oleh verba intransitif, kata tersebut juga sangat potensial mewatasi fungsi SUBJ dan predikat yang diperankan oleh frasa adjektiva. Data di atas sekaligus membentuk model klausa intransitif ketiga yang menempatkan adjektiva sebagai predikatnya sebagai berikut.

\section{E. FN diwatasi Demonstratif Itu (+) Adjektiva dalam Frasa Koordinatif}

\section{KLAUSA INTRANSITIF $4=(\mathrm{S})$ FN $\{\mathbf{N}+\mathrm{itu}\}(+)(\mathrm{P})$ Adjektiva Tunggal} Jenis Nilai

(24) Anak itu begitu lucu. Begitu montok. Begitu menawan. (DTW, 2007 : 50, 9-10)

(25) Dia polos, periang dan cerdik. (DTW, $2007: 190,25$ )

(26) Anak itu dekat sekali sama bapaknya. (BIP, 2003 : 70, 21-26)

F. $\mathbf{S}=$ Pronomina (+) FAdj $\{$ Negasi + Adjektiva $\}$

KLAUSA INTRANSITIF 5 = $($ S) FN $\{$ N + itu $\}(+)(P)$ Adjektiva Tunggal dalam frasa Koordinatif

G. $\mathbf{S}=$ Pronomina $(+)$ FAdj $\{$ Modalitas + Adjektiva $\}$

(27) Dia pasti sedih (BIP, 2003 :252, 26-28)

KLAUSA INTRANSITIF $6=(\mathrm{S})$ Pronomina Tunggal $(+)(\mathrm{P})$ Frasa Adjektiva \{modalitas + adjektiva nilai properti manusia

H. $\mathbf{S}=$ Pronomina $(+)$ FAdj $\{$ Pewatas + Adjektiva Turunan $\}$

(28) Dia cukup terpelajar. (DTW, 2007: 128, 13)

KLAUSA INTRANSITIF $6=(\mathrm{S})$ Pronomina Tunggal $(+)(\mathrm{P})$ Frasa

Adjektiva \{́pewatas adjektiva + adjektiva turunan afiksasi 
I. $\mathbf{S}=$ Pronomina (+) FAdj $\{$ Aspek + Adjektiva $\}$

(29) Tekadnya sudah mantap. (BIP, 2003 :253, 3-6)

(30) Dia sudah jinak seperti anak kucing. (BIP, 2003 : 188,11-12)
KLAUSA INTRANSITIF 7 = (S) FN $\{\mathbf{N}+$ pronominal (-nya) $\}(+)(\mathbf{P})$
Frasa Adjektiva \{modalitas + adjektiva nilai nomina abstrak

J. $\quad \mathbf{S}=$ Pronomina (+) F Adj\{Pewatas + Adjektiva $\}$

(31) Kondisinya belum sehat betul. (BIP, 2003 : 147, 17-21)

(32) Ibunya sama sekali tidak ingat padanya! (BIP,2003: 23,2)
KLAUSA INTRANSITIF $7=$ (S) FN $\{\mathbf{N}+\operatorname{pronominal}(-n y a)\}(+)(\mathrm{P})$
Frasa Adjektiva \{negasi\{tidak/belum $\}+$ adjektiva + FP berfungsi ADJ (opsional)

K. $\mathbf{S}=$ FN (+) F Adj $\{$ Pewatas + Adjektiva $\}$

(33) Kamarnya cukup besar. (BIP, 2003 :228, 18-27)

(34) Gumamnya lirih. (BIP, $2003: 53,8-9$ )

Terlihat dari data di atas, klausa adjektiva yang menempati fungsi predikatif mempunyai pemarkah SUBJ FN kamarnya dalam data (15) dan gumamnya dalam data (16) yang dibentuk oleh nomina dan frasa nomina dimana pronominal pembentuknya sekaligus berfungsi sebagai pembatas dan pemarkah yang jelas membatasi fungsinya sebagai satu-satunya argumen yang diminta oleh satu-satunya konstituen predikat sesudahnya. Data di atas mengantar kita pada model bentukan klausa intransitif berpredikat frasa adjektiva selanjutnya seperti yang terlihat dalam data berikut.

\section{KLAUSA INTRANSITIF $8=$ (S) FN $\{\mathbf{N}+$ pronominal (-nya) $\}$ (+) (P) Frasa Adjektiva \{negasi \{tidak/belum\} + adjektiva + FP berfungsi ADJ (opsional)}

Adjektiva yang bisa berfungsi sebagai predikat intransitif seperti yang terlihat dalam data di atas menyebabkan istilah verba intransitif lebih berterima diganti dengan istilah predikat intransitif karena secara sintaktis, tidak hanya verba intransitif yang bisa berfungsi sebagai predikat dalam klausa intransitif, namun kategori lain juga bisa dengan catatan, mempunyai perilaku sintaktis yang sama dengan verba 
intransitif dalam klausa intransitif. Salah satu perilaku intransitif dimaksud adalah mempunyai kemampuan mengikat satu argumen inti saja dan argumen non-inti yang mengikutinya adalah adjung yang didahului atau tanpa frasa preposisi. Ketika sebuah adjektiva dapat berfungsi sebagai predikat intransitif, adjektiva tersebut berfungsi sebagai argumen predikat intransitif.

Dalam struktur klausa yang menempatkan frasa adjektiva memerankan fungsi predikatif intransitif ini, pelesapan argumen SUBJ yang berfungsi sebagai agen pelaku perbuatannya sebagai argumen predikat memungkinkan terjadi. . SUBJ akan melesap pada kondisi klausa yang menempatkan frasa adjektiva sebagai predikat dalam klausa intransitif dan diikuti oleh klausa komplemen yang berfungsi sebagai adjung dengan pelesapan pemarkahnya, seperti yang terlihat dalam data berikut.

35. “(Saya) senang sekali bertemu dengan anda, Soni” (MDAP, 2001 : 19, 19-20) lesap PRED

35. (Saya) Sulit sekali menendangnya dari hatimu. (MDAP, $2001: 20,31-32$ ) lesap PRED

Mengamati keseluruhan analisis di atas, dalam subbab ini dirumuskan perilaku khas, sekaligus ciri khas adjektiva disaat memerankan fungsi sebagai predikat intransitif dilihat dari lingkungan sintaktis kemunculanya.

\section{SIMPULAN}

Analisis fungsi Predikatif yang dapat diisi oleh kelas kata adjektiva merumuskan simpulan bahwa adjektiva dalam memerankan fungsinya sebagai pengisi slot predikat intransitif memungkinkan bisa mengikat satu argumen dan bisa diikuti oleh argumen non-inti dan berterima dilekati properti dirinya dan juga properti kelas kata lain yaitu kelas kata verba. Adjektiva dalam fungsinya sebagai pengisi slot dimaksud juga cenderung memiliki bentuk asalnya tanpa pemarkah morfologis. Lebih daripada itu, dan merupakan Keunikan dari kelas kata adjektiva dalam fungsi predikat intransitif adalah kemampuannya memiliki integritas agen yang kuat dan memiliki fitur subyek yang sama.

Ditemukan dalam data, ciri khas yang melekat pada adjektiva disaat memerankan fungsi tersebut terletak pada kekhasan yang ada pada sejumlah properti yang melekatinya, diantaranya adalah penanda subyek, penanda aspek, kemunculan modifier tertentu sebelum posisi inti, posisi dan sifat kehadiran inti dan kemunculan modifier tertentu sesudah posisi inti.(1) Pronomina (-nya) sebagai penanda ganti orang ketiga tunggal dan kata ganti demonstratif itu 
adalah dua penanda subyek yang kemunculannya bersifat wajib diantara SUBJ dan predikat dalam klausa intransitif;

Kemunculan aspek sudah yang mewatasi frasa adjektiva muncul dalam klausa intransitif dan kemunculannya bersifat optional; (3) Kemunculan modifier/atribut sebelum inti diwakili oleh modalitas pasti yang muncul sebelum frasa adjektiva yang berfungsi sebagai predikat. Kemunculannya berfungsi sebagai pra-inti sekaligus pembatas yang jelas antara fungsi SUBJ dan Predikat. Kemunculan modalitas ini bersifat optional; (4) Kemunculan inti yang berupa frasa adjektiva disyaratkan wajib harir dan berfungsi sebagai penentu apakah suatu kategori yang berupa kata maupun frasa dapat berfungsi sebagai predikat intransitif atau tidak dan (5) Kemunculan kata saja dan nih merupakan kata yang berfungsi sebagai modifier/atribut dalam klausa intransitif berpredikat frasa adjektiva. Kemunculannya sebagai modifier meskipun berperan sentral dalam mempertegas kemunculan PRED, namun kehadirannya bersifat opsional.

\section{UCAPAN TERIMA KASIH}

Penulis mengucapkan terima kasih kepada mitra bestari atas masukan dan kritikan yang sangat membangun demi perbaikan artikel ini.

\section{DAFTAR PUSATAKA}

Ackerman, Farel dan Gert Webelhuth. 1998. A Theory of Predicate. Stanford, California: CSLI.

Alwi, Hasan, dkk. 2000. Tata Bahasa Baku Bahasa Indonesia. Edisi Ketiga. Jakarta: Balai Pustaka.

Arka, I Wayan. 2000. Beberapa Aspek Intransitif Terpilah pada Bahasa-bahasa Nusantara: Sebuah Analisis LeksikalFungsional. Dalam Bambang Kaswanti Purwo (Ed.). Kajian Serba Linguistik: 423-510. Jakarta: Universitas Katolik Indonesia Atma Jaya dan PT BPK Gunung Mulia.

Artawa, Ketut. 2000. Alternasi Diatesis pada Beberapa Bahasa Nusantara. Dalam Bambang Kaswanti Purwo (Ed.) Kajian Serba Linguistik untuk Anton MoelionoPereksa Bahasa. Jakarta: Universitas Katolik Atma Jaya dan PT BPK Gunung Mulia.

Dixon, R.M.W. 2010. Basic Linguistics Theory. Oxford: Oxford University Press.

Hinrichs, Erhard; Andreas Kathol; Tsuneko Nakazawa (Ed.). 1998. Syntax and Semantics: Complex Predicates in in Nonderivational Syntax. Volume 30. San Diego, California: Academic Press.

Kordoni, Valia. 2003. Valence Alternation in German: An LMT Analysis. Dalam Mariam Butt dan Tracy Holloway King (Ed.). Proceedings of The LFG03 Conference (serial online), November, [cited 2004 Des. 28]. Available from: URL: $\quad$ http://cslipublications.stanford.edu/LFG/8/ lfg03.html. Stanford: CSLI.

Kridalaksana, Harimurti. 2001. Kamus Linguisrtik. Edisi Ketiga. Jakarta: Gramedia Pustaka Utama.

Kroeger, Paul R. 2004. Analyzing Syntax: A Lexical Functional Approach. Cambridge: Cambridge University Press.

Nasution, S. 2003. Metode Research (Penelitian Ilmiah). Jakarta: Bumi Aksara.

O'Grady, William; John Archibald; Mark Aronoff; dan Janie Rees-Miller (Ed.). 2001. Contemporary Linguistics: An Introduction. Fourth Edition. Boston: Bedford/St.Martin's.

Panitia Pengembangan Bahasa Indonesia, 
2000. Pedoman Umum Ejaan Bahasa

Indonesia Yang Disempurnakan.

Jakarta : Pusat Bahasa, Departemen

Pendidikan Nasional.

Stassen, Leon. 1997. Intransitive Predicates. Oxford : Clarendon Press.

Sugono, dendy. 1995. Pelesapan Subyek dalam Bahasa Indonesia. Jakarta: Pusat Pembinaan dan pengembangan. 